Jurnal Keperawatan Silampari

Volume 4, Nomor 2, Juni 2021

e-ISSN: 2581-1975

p-ISSN: 2597-7482

DOI: https://doi.org/10.31539/jks.v4i2.1920

\title{
LATIHAN ROM PASIF UNILATERAL DAN BILATERAL TERHADAP PENINGKATAN KEKUATAN OTOT AKIBAT STROKE ISKEMIK
}

\author{
Ratna Fithriyah Sholihany ${ }^{1}$, Agung Waluyo ${ }^{2}$, Diana Irawati $^{3}$ \\ Universitas Muhammadiyah Jakarta ${ }^{1,3}$ \\ Universitas Indonesia ${ }^{2}$ \\ ratnafithriyah2018@gmail.com ${ }^{1}$
}

\begin{abstract}
ABSTRAK
Penelitian ini bertujuan untuk mengetahui perbandingan efektifitas antara latihan ROM unilateral dan ROM bilateral terhadap peningkatan kekuatan otot pada klien paska rawat inap dengan hemiparise akibat stroke iskemik. Metode penelitian yang digunakan adalah quasy experimental two group pre dan post test design. Hasil penelitian ada pengaruh kedua kelompok terhadap peningkatan kekuatan otot dengan p-value 0,000, Simpulan, latihan ROM bilateral memberikan dampak lebih tinggi dalam meningkatkan kekuatan otot dibandingkan dengan Lathan ROM unilateral.
\end{abstract}

Kata Kunci : Kekuatan Otot, ROM Bilateral, ROM Unilateral, Stroke Iskemik

\section{ABSTRACT}

This study aims to compare the effectiveness of unilateral ROM and bilateral ROM exercises to increase muscle strength in post-hospitalized clients with hemiparesis due to ischemic stroke. The research method used is a quasi experimental two group pre and post test design. The results showed that there was an effect of both groups on increasing muscle strength with a p-value of 0.000, in conclusion, bilateral ROM exercises had a higher impact on increasing muscle strength compared to unilateral ROM exercises.

Keywords: Muscle Strength, Bilateral ROM, Unilateral ROM, Ischemic Stroke

\section{PENDAHULUAN}

Stroke termasuk salah satu penyakit yang meninggalkan dampak berupa kecacatan. Diperkirakan sepertiga dari jumlah penderita stroke di dunia mengalami kecacatan yang permanen. Stroke terjadi ketika pembuluh darah otak gagal menyuplai oksigen ke sel-sel otak. Jika sel otak tidak menerima nutrisi dan oksigen dari darah, maka terjadilah kerusakan pada sel otak (Lestari, 2019). Gejala stroke biasanya muncul secara tiba-tiba, dengan kehilangan kekuatan pada salah satu sisi tubuh, bingung, sulit bicara atau sulit memahami, ada masalah pada penglihatan, sulit berjalan, sakit kepala, dan hilang keseimbangan (Setyoadi et al., 2018).

Faktor risiko penyakit stroke ada yang dapat dimodifikasi dan ada yang tidak dapat dimodifikasi. Faktor risiko yang tidak dapat dimodifikasi yaitu faktor yang tidak dapat dirubah dengan gaya hidup, misalnya usia. Sementara faktor risiko yang dapat dimodifikasi yaitu faktor yang dapat diubah seperti gaya hidup, diantaranya yaitu faktor hipertensi dan merokok (Mutiarasari, 2019). 
Menurut World Health Organization (WHO), penyakit stroke merupakan penyakit nomor dua yang menyebabkan kematian hampir di seluruh dunia dan nomor tiga penyebab utama disabilitas (Johnson et al., 2016). Di Amerika Serikat, stroke menjadi penyakit nomor lima yang menyebabkan kematian, setelah penyakit jantung, kanker, dan penyakit pernafasan kronis (Alifudin \& Ediati, 2019).

Menurut Kementrian Kesehatan Republik Indonesia 2018, prevalensi stroke (permil) berdasarkan diagnosis pada penduduk umur lebih dari 15 tahun, Indonesia mengalami kenaikan angka kejadian stroke dari tahun 2013 sampai 2018, yaitu 2013 sebanyak 7\%o, sedangkan pada tahun 2018 naik menjadi 10,9\%o. Dengan spesifikasi laki-laki 11,0\%o, perempuan 10,9\%o (Riskesdas, 2018).

Perubahan pola hidup seperti makan tidak teratur, kurang olahraga, jam kerja berlebihan serta konsumsi makanan cepat saji sudah menjadi kebiasaan lazim yang berpotensi menimbulkan serangan stroke (Anita et al., 2018). Stroke merupakan masalah kesehatan dan perlu mendapat perhatian khusus. Berdasarkan kejadian yang ada dilapangan pemberian mobilisasi dini pada pasien stroke belum mendapat perhatian. Kurangnya aktivitas fisik setelah stroke dapat menghambat rentang gerak sendi sehingga apabila hal ini terus terjadi akan menyebabkan ketergantungan total, kecacatan bahkan sampai kematian (Anita et al., 2018).

Kematian yang diakibatkan oleh stroke sekitar $10-30 \%$ pasien yang dirawat dan 70-90\% pasien yang hidup pasca stroke. Sekitar $90 \%$ pasien mengalami kelumpuhan atau kelemahan separuh tubuhnya. Pasien stroke yang tidak segera mendapatkan penanganan medis dapat mengakibatkan kelumpuhan dan juga menimbulkan komplikasi, salah satunya seperti terjadinya gangguan mobilisasi, gangguan fungsional, gangguan aktivitas sehari-hari dan kecacatan yang tidak dapat disembuhkan. Gangguan fungsional yang umum terjadi pada penderita stroke ialah pada ekstremitas atas, diantaranya seperti kehilangan kontrol yang dapat menurunnya kekuatan otot (Anggraini et al., 2018).

Salah satu metode yang digunakan untuk memulai aktivitas fisik sebelum pasien siap melakukan latihan ROM dengan bola karet adalah menggerakkan lengan dengan perlahan. Hal ini sering dilakukan untuk pasien stroke dirumah sakit yang tidak mampu melakukan aktivitas. ROM merupakan latihan yang digunakan untuk memperbaiki pergerakan sendi secara normal untuk meningkatkan tonus otot. Melakukan latihan ROM secara dini dapat meningkatkan kekuatan otot sehingga dapat menstimulasi motor unit semakin banyak yang terlibat, maka akan terjadi peningkatan kekuatan otot (Anggriani et al., 2018).

Pasien stroke memerlukan rehabilitasi untuk meminimalkan cacat fisik, rehabilitas harus dimulai sedini mungkin secara cepat dan tepat sehingga dapat membantu pemulihan fisik yang lebih cepat dan optimal serta menghindari kelemahan otot. Agar tidak terjadi kelemahan otot bisa dilakukan ROM dengan perlahan dapat membantu menyembuhan kelemahan otot pasien. Setelah penderita stroke mulai melanjutkan kegiatan fisik dengan terapi fisik yang aman, dan nafsu makan akan mulai membaik. Peningkatan secara bertahap dapat membantu mencegah keputusasaan. Otot yang terganggu akibat stroke masih bisa membaik berkat latihan ROM (Nurazizah et al., 2020).

Studi pendahuluan telah dilakukan pada bulan Desember 2019 di Ruang Cendana 2 Rumah Sakit Bhayangkara Tk. I Raden Said Sukanto, dengan kejadian kasus stroke yang tinggi terutama kasus stroke iskemik dengan hemiparise. Ditemukan 10 orang klien stroke iskemik dengan 6 orang diantaranya mengalami hemiparese. Perawat 
biasanya melakukan intervensi dan bekerja sama atau koordinasi dengan keluarga klien untuk melakukan latihan ROM pada sisi yang mengalami hemiparise namun latihan ini dilakukan tidak terprogram. Pasien dengan diagnosa stroke iskemik rata-rata lama rawatnya adalah 7-10 hari, tergantung kondisi klien, setelah klien diberikan terapi dan kondisi klien stabil namun tidak jarang pula klien paska perawatan pulang masih dengan kondisi hemiparesis karena butuh waktu cukup lama untuk pemulihan, maka klien diperbolehkan untuk pulang oleh dokter dan selanjutnya dianjurkan untuk kontrol/berobat jalan.

\section{METODE PENELITIAN \\ Rancangan Penelitian}

Rancangan penelitian yang digunakan adalah ini menggunakan desain quasy experimental two group pre-post design yaitu jenis penelitian eksperimen, dimana observasi dilakukan sebanyak dua kali, yaitu sebelum (pre-test) dan sesudah eksperimen (post-test). Dalam penelitian ini menggunakan dua kelompok intervensi yaitu kelompok intervensi I diberikan latihan ROM pasif unilateral, kelompok intervensi II merupakan kelompok yang diberikan intervensi latihan ROM pasif bilateral.

\section{Populasi dan Sampel}

Populasi pada peneitian ini adalah seluruh klien yang didiagnosa stroke iskemik. Sedangkan sampel dipilih berdasarkan kriteria : 1) Pasien didiagnosa stroke iskemik, 2) Pasien paska rawat inap, 3) Mengalami hemipasise ekstemitas atas dan bawah, 4) Kekuatan otot antara 1-3, 5) Bersedia menjadi responden, 6) Memiliki nomor Whats App yang aktif.

\section{Tahapan Penelitian}

Peneliti mengumpulkan data melalui instrument penelitian berupa kuisioner dan hasil observasi intervensi melalui video call/whatssapp yaitu pada klien paska rawat inap akibat stroke iskemik di salah satu Rumah Sakit di Jakarta Timur yang berjumlah 52 orang.

\section{HASIL PENELITIAN}

Tabel. 1

Karakteristik Responden Usia, Jenis Kelamin, Pendidikan, Riwayat Penyakit, dan IMT Responden Kelompok ROM Unilateral dan ROM Bilateral

\begin{tabular}{|c|c|c|c|c|c|}
\hline Karakteristik Responden & Median & Min-Max & $95 \% \mathrm{CI}$ & $\mathrm{f}$ & $\%$ \\
\hline \multicolumn{6}{|l|}{ ROM Unilateral } \\
\hline Usia & 58,00 & $45-85$ & $55,09-63,14$ & & \\
\hline \multicolumn{6}{|l|}{ Jenis Kelamin } \\
\hline Laki-Laki & & & & 21 & 80,8 \\
\hline Perempuan & & & & 5 & 19,2 \\
\hline \multicolumn{6}{|l|}{ Pendidikan } \\
\hline SD & & & & 2 & 7,7 \\
\hline SMP & & & & 15 & 57,7 \\
\hline SMA & & & & 7 & 26,9 \\
\hline PT & & & & 2 & 7,7 \\
\hline \multicolumn{6}{|l|}{ Riwayat Penyakit } \\
\hline Ya & & & & 17 & 65,4 \\
\hline Tidak & & & & 9 & 34,6 \\
\hline
\end{tabular}




\begin{tabular}{|c|c|c|c|c|c|}
\hline \multicolumn{6}{|l|}{ IMT } \\
\hline Obesitas & & & & 10 & 38,5 \\
\hline BB lebih & & & & 9 & 34,6 \\
\hline BB normal & & & & 7 & 26,9 \\
\hline \multicolumn{6}{|l|}{ ROM Bilateral } \\
\hline Usia & 58,00 & $45-75$ & $54,90-62,25$ & & \\
\hline \multicolumn{6}{|l|}{ Jenis Kelamin } \\
\hline Laki-Laki & & & & 19 & 73,1 \\
\hline Perempuan & & & & 7 & 26,9 \\
\hline \multicolumn{6}{|l|}{ Pendidikan } \\
\hline SD & & & & 14 & 53,8 \\
\hline SMP & & & & 9 & 34,6 \\
\hline SMA & & & & 3 & 11,5 \\
\hline \multicolumn{6}{|l|}{ Riwayat Penyakit } \\
\hline Ya & & & & 16 & 61,5 \\
\hline Tidak & & & & 10 & 38,5 \\
\hline \multicolumn{6}{|l|}{ IMT } \\
\hline Obesitas & & & & 11 & 42,3 \\
\hline BB lebih & & & & 7 & 26,9 \\
\hline BB normal & & & & 8 & 30,8 \\
\hline
\end{tabular}

Berdasarkan tabel 1 nilai tendensi sentral usia responden menunjukan bahwa nilai median responden pada kelompok unilateral dan bilateral memiliki nilai median yang sama yaitu 58 tahun, tetapi usia minimal pada kelompok unilateral adalah 45 tahun dan usia maksimal adalah 85 tahun, sedngkan pada kelompok bilateral usia minimal adalah 45 tahun dan maksimal adalah 75 tahun.

Karakteristik jenis kelamin menunjukan bahwa responden pada kelompok ROM unilateral terbanyak adalah laki-laki yaitu $84,6 \%$. Begitupun responden pada kelompok ROM bilateral menunjukan bahwa jenis kelamin laki-laki paling banyak yaitu 76,9\%. Karakteristik pendidikan responden pada kelompok ROM unilateral menunjukan bahwa pendidikan terbanyak adalah SMP sebanyak 57,7\%. Sedangkan responden pada kelompok ROM bilateral menunjukan bahwa pendidikan terbanyak adalah SD sebanyak 53,8\%.

Karakteristik responden riwayat penyakit sebelumnya menunjukan bahwa responden pada kelompok ROM unilateral terbanyak memiliki riwayat penyakit sebesar $65,4 \%$, begitu pula responden pada kelompok ROM bilateral menunjukan bahwa responden terbanyak memiliki riwayat penyakit sebesar $61,5 \%$. Karakteristik responden IMT (Indeks Masa Tubuh) menunjukan bahwa responden terbanyak pada kelompok ROM unilateral adalah obesitas sebesar 38,5\%, sedangkan responden pada kelompok ROM bilateral menunjukan bahwa responden terbanyak adalah obesitas sebesar $42,3 \%$.

Tabel. 2

Pre-test dan Post-Test Kekuatan Otot Responden Kelompok ROM Unilateral dan Kelompok ROM Bilateral

\begin{tabular}{llccc}
\hline Kekuatan Otot & & Median & Min-Man & 95\%CI \\
\hline ROM Unilateral & & & & \\
\hline & Pre-Test & 2 & $1-3$ & $1,78-2,38$ \\
& Post-Test & 3 & $1-4$ & $2,49-3,20$ \\
\hline ROM Bilateral & & & & \\
\hline & Pre-Test & 2 & $1-3$ & $1,67-2,25$ \\
& Post-Test & 4 & $2-4$ & $3,04-3,73$ \\
\hline
\end{tabular}


Berdasarkan tabel 2 menunjukan bahwa distribusi data kekuatan otot pada kelompok ROM unilateral dari 26 responden menunjukan bahwa nilai median pre-test 2 dan nilai median post-test 3. Selain itu nilai minimal pada pre-tes 1 dan maksimal 3 sedangkan pada saat post-test nilai minimal 1 dan nilai maksimal 4. Kekuatan otot pada kelompok ROM bilateral dari 26 responden menunjukan bahwa nilai median pre-test 2 dan nilai median post test 4 . Selain itu nilai minimal pada pre-tes 1 dan maksimal 3 sedangkan pada saat post-test nilai minimal 2 dan nilai maksimal 4.

Tabel. 3

Hasil Uji Bivariat Karakteristik Responden dengan Kekuatan otot Kelompok ROM Unilateral dan Bilateral Paska Rawat Inap

\begin{tabular}{|c|c|c|c|c|}
\hline No & Variabel Indepeden & Variabel Dependen & P-Value & Keterangan \\
\hline \multicolumn{5}{|c|}{ Kelompok ROM Unilateral } \\
\hline 1 & Usia & \multirow{5}{*}{ Kekuatan Otot } & 0,000 & Signifikan \\
\hline 2 & Pendidikan & & 0,561 & Tidak Signifikan \\
\hline 3 & Riwayat Penyakit & & 0,010 & Signifikan \\
\hline 4 & IMT & & 0,000 & Signifikan \\
\hline 5 & Jenis Kelamin & & 0,705 & Tidak Signifikan \\
\hline \multicolumn{5}{|c|}{ Kelompok ROM Bilateral } \\
\hline 1 & Usia & \multirow{5}{*}{ Kekuatan Otot } & 0,001 & Signifikan \\
\hline 2 & Pendidikan & & 0,915 & Tidak Signifikan \\
\hline 3 & Riwayat Penyakit & & 0,002 & Signifikan \\
\hline 4 & IMT & & 0,001 & Signifikan \\
\hline 5 & Jenis Kelamin & & 0,483 & Tidak Signifikan \\
\hline
\end{tabular}

Berdasarkan tabel 3 menjelaskan bahwa hasil uji Korelasi Spearman variabel usia baik kelompok ROM unilateral dan ROM bilateral terhadap kekuatan otot didapatkan $p$-value $<0,05$ (0,000 dan 0,001), artinya usia berhubungan secara signifikan dengan kekuatan otot. Hasil uji Kruskal-Wallis Test variabel pendidikan baik kelompok ROM unilateral dan ROM bilateral dengan kekuatan otot didapatkan $p$-value $>0,05(0,561$ dan 0,515artinya pendidikan tidak berhubungan secara signifikan dengan kekuatan otot.

Dari hasil uji Mann-Withney Test variabel riwayat penyakit baik kelompok ROM unilateral dan ROM bilateral dengan kekuatan otot didapatkan p-value $<0,05(0,010$ dan 0,002), $p$-value tersebut bermakna bahwa riwayat penyakit berhubungan secara signifikan dengan kekuatan otot. Uji Krusal-Wallis Test variabel IMT baik kelompok ROM unilateral dan ROM bilateral dengan kekuatan otot didapatkan p-value <0,05 $(0,000$ dan 0,001), p-value tersebut bermakna bahwa IMT berhubungan secara signifikan dengan kekuatan otot. Hasil uji Mann-Withney Test variabel jenis kelamin baik kelompok ROM unilateral dan ROM bilateral dengan kekuatan otot didapatkan $p$ value $>0,05$ (0,705 dan 0,483), p-value tersebut bermakna bahwa jenis kelamin tidak berhubungan secara signifikan dengan kekuatan otot.

Tabel. 4

Hasil Uji Wilcoxon Perbedaan Pre-test dan Post-Test

Kekuatan Otot Responden Kelompok ROM Unilateral

\begin{tabular}{lcccc}
\hline Kekuatan otot & Ranks & f & Z & p-value \\
\hline Pre-Test ROM Unilateral & Negative & 0 & $-4,472$ & 0,000 \\
Post-Test ROM Unilateral & Positive & 20 & & \\
& Ties & 6 & & \\
\cline { 2 - 3 } & Jumlah & 26 & & \\
\cline { 2 - 3 } & & \multicolumn{2}{c}{2} \\
\hline
\end{tabular}


Berdasarkan tabel 4 menunjukkan bahwa hasil uji wilcoxon antara kekuatan otot pre-test dan post-test kelompok unilateral didapatkan nilai $\mathrm{Z}$ sebesar -4,472 dan $p$-value 0,000 ( $p$-value $<0,05$ ), dengan demikian dapat disimpulkan bahwa terdapat perbedaan kekuatan otot antara sebelum dilakukan latihan ROM unilateral dan sesudah latihan ROM unilateral.

Tabel. 5

Hasil Uji Wilcoxon Perbedaan Pre Test dan Post Test

Kekuatan Kelompok ROM Bilateral dengan Uji Wilcoxon

\begin{tabular}{llccc}
\hline Kekuatan otot & Ranks & f & Z & P-Value \\
\hline Pre Test ROM Bilateral & Negative & 0 & $-4,608$ & 0,000 \\
Post Test ROM Bilateral & Positive & 26 & & \\
& Ties & 0 & & \\
\cline { 2 - 3 } & Jumlah & 26 & & \\
\hline
\end{tabular}

Berdasarkan tabel 5 menunjukkan bahwa hasil uji wilcoxon antara kekuatan otot pre-test dan post-test kelompok bilateral didapatkan nilai $\mathrm{Z}-4,608$ dan $p$-value 0,000 ( $p$-value <0,05), dengan demikian dapat disimpulkan bahwa terdapat perbedaan kekuatan otot yang bermakna antara sebelum dan sesudah latihan ROM bilateral.

Tabel. 6

Hasil Uji Mann-Whitney Post-Test Kekuatan Otot Responden pada Kelompok ROM Unilateral dan ROM Bilateral

\begin{tabular}{llccc}
\hline \multicolumn{1}{c}{ Kekuatan otot } & N & Mean Rank & Z & P-Value \\
\hline Post-Test ROM Unilateral & 26 & 22,04 & $-2,259$ & 0,024 \\
Post-Test ROM Bilateral & 26 & 30,96 & & \\
\hline
\end{tabular}

Berdasarkan tabel 6 menunjukan bahwa hasil uji Mann-Whitney antara kekuatan otot post-test kelompok unilateral dan post-test kelompok bilateral didapatkan nilai Z 2,259 dan p-value 0,024 ( $p$-value < 0,05), dengan demikian dapat disimpulkan bahwa terdapat perbedaan kekuatan otot yang bermakna antara setelah dilakukan latihan ROM unilateral dan setelah latihan ROM bilateral.

Selain itu didapatkan juga Mean Rank post- test kelompok ROM unilateral sebesar 22,06 dan mean rank post-test kelompok ROM bilateral sebesar 30,96, dari kedua kelompok tersebut menunjukkan bahwa nilai mean rank post-test pada kelompok ROM bilateral lebih besar dibandingkan dengan nilai mean rank post-test kelompok ROM unilateral.

\section{PEMBAHASAN}

\section{Pengaruh Latihan ROM Unilateral terhadap Kekuatan Otot}

Pasien stroke memerlukan rehabilitasi untuk meminimalkan cacat fisik, rehabilitas harus dimulai sedini mungkin secara cepat dan tepat sehingga dapat membantu pemulihan fisik yang lebih cepat dan optimal serta menghindari kelemahan otot. Agar tidak terjadi kelemahan otot bisa dilakukan ROM dengan perlahan dapat membantu menyembuhan kelemahan otot pasien. Setelah penderita stroke mulai melanjutkan kegiatan fisik dengan terapi fisik yang aman, dan nafsu makan akan mulai membaik. Peningkatan secara bertahap dapat membantu mencegah keputusasaan. Otot yang 
terganggu akibat stroke masih bisa membaik berkat latihan ROM (Nurazizah et al., 2020).

Menurut Indrawati et al., (2018) pelaksanaan ROM di Rumah Sakit bukan lagi sebagai kebutuhan pelengkap, melainkan sudah menjadi keharusan melihat dari tingkat pasien dengan penyakit stroke terus meningkat setiap tahunnya. Latihan ROM di Rumah Sakit yang diberikan oleh perawat untuk pasien stroke bertujuan untuk memperbaiki defisit neurologis khususnya fungsi motorik. Latihan ROM menjadi salah satu intervensi keperawatan untuk pasien stroke yang mengalami gangguan mobilitas fisik, yang disebabkan oleh bed rest yang cukup lama atau karena hemiparesis. Dalam pelaksanaan terapi ini terdapat kriteria pasien stroke yang diperbolehkan atau dianjurkan menjalankan terapi, yaitu pasien dengan keadaan koma, atau bed rest total. Sedangkan pasien yang tidak dianjurkan pemberian terapi yaitu pasien yang apabila ada pergerakan aktif dapat menghambat proses penyembuhan cedera (Indrawati et al., 2018).

Latihan ROM harus segera dilakukan sedini mungkin, karena jika tidak segera dilakukan akan berdampak terjadinya atrofi sel-sel otot, penurunan kemampuan kontraksi otot, kekakuan sendi, adanya keluhan nyeri saat melakukan pergerakan, dan secara umum akan mengakibatkan keterbatasan dalam beraktifitas, kondisi ini akan memperberat atau memperparah keadaan pasien dan menimbulkan kecacatan. Hal ini sesuai dengan yang diungkapkan dari hasil penelitian bahwa program rehabilitasi atau mobilisasi sedini mungkin adalah salah satu faktor kunci dalam perawatan pasien stroke (Anita et al., 2018).

Penelitian yang dilakukan Kristiani tahun 2018 menunjukkan bahwa terdapat pengaruh latihan ROM terhadap kekuatan otot pada pasien stroke setelah 1 bulan menjalani latihan ROM yang menunjukkan terdapat peningkatan kekuatan otot setelah latihan Range of motion dari skala 3 ke skala 4 dan skala 4 meningkat menjadi skala 5. Latihan ini dilakukan dengan frekuensi 2x sehari dalam 5 hari (Kristiani, 2018; Syahrim et al., 2019).

Hasil penelitian Nababan \& Giawa (2019) menunjukkan bahwa nilai rerata sebelum dilakukan intervensi adalah 2,50 dan pada saat setelah dilakukan intervensi selama 5 hari didapatkan nilai rerata 10,00 dengan p-value sebesar $0,059<0,05$ artinya bahwa ada pengaruh latihan ROM pada pasien stroke iskemik terhadap peningkatan kekuatan otot.

Pendekatan latihan pada klien stroke dapat dilakukan dengan pendekatan unilateral dan bilateral. Pendekatan unilateral disebut juga pola tradisional atau Compensantory Rehabilitasi. Latihan unilateral yang selama ini dilakukan pada klien stroke, hanya melatih sebagian dari fungsi tangan atau kaki saja. Pada Pendekatan unilateral terjadi inhibisi pada gerakan lengan kontra lateral, sehingga latihan unilateral ini hanya mengaktivasi satu bagian otak.

\section{Pengaruh ROM Bilateral terhadap Kekuatan Otot}

Penelitian Nurtanti \& Ningrum (2018) dilakukan latihan Range Of Motion (ROM) aktif yang dilakukan $2 \mathrm{x}$ sehari setiap pagi dan sore dengan waktu setiap latihan 20 menit selama 1 bulan. Pada penelitian ini di dapatkan hasil terjadi kenaikan kekuatan otot dari skala 2 menjadi skala 3 setelah diberikan latihan Range Of Motion (ROM) aktif. Adanya pengaruh dari pemberian latihan ROM aktif untuk meningkatkan kekuatan otot pada penderita stroke. 
Kekuatan otot adalah adalah kemampuan otot menahan beban baik berupa beban eksternal maupun beban internal. Kekuatan dari sebuah otot umumnya diperlukan dalam melakukan aktifitas. Se-mua gerakan merupakan hasil dari adanya peningkatan tegangan otot sebagai respon motorik. Kekuatan otot dapat digambarkan sebagai kemampuan otot menahan beban berupa beban eksternal (external force) maupan beban internal (internal force). Kekuatan otot sangat berhubungan dengan sistem neuromuskuler yaitu sebera-pa besar kemampuan sistem saraf meng-aktifasi otot untuk melakukan kontraksi, sehingga semakin banyak serat otot yang teraktifasi, maka semakin besar pula kekuatan yang dihasilkan otot tersebut (Wahyuningsih, 2017).

Pada penelitian Olviani (2017) evaluasi keperawatan dilakukan setelah pasien mendapatkan latihn ROM selama kurang lebih 20 menit pada waktu yang telah ditetapkan 1 bulan. Hasil dari evaluasi keperawatan mayoritas responden mengatakan kelemahan otot berkurang. Hal tersebut sudah sesuai dengan kriteria hasil yang telah ditetapakan peneliti pada tahap perencanaan keperawatan, sehingga masalah hambatan mobilitas fisik dapat teratasi sebagian dan tindakan latihan ROM dilanjutkan secara rutin, hal ini karena laju proses terapi non farmakologi ROM membutuhkan waktu yang lebih lama dan tidak bisa secepat proses terapi farmakologi.

Alasan utama dilakukannya latihan bilateral didasarkan bahwa banyak sekali aktifitas yang dilakukan sehari-hari yang memerlukan kedua tangan, misalnya dalam perawatan diri seperti mandi, berpakaian, makan, toilet. Pada saat seseorang terkena stroke dan mengalami defisit motorik akibat parese pada ekstremitas atas, maka pasien akan mengalami hambatan dalam melakukan aktivitas sehari-hari terutama aktvitas yang dilakukan dengan menggunakan kedua tangan. Untuk aktivitas sehari-hari yang bisa digunakan hanya dengan satu tangan, mungkin masih bisa dikompensasi oleh tangan yang sehat, tetapi penggunaan tangan yang sehat secara terus menerus akan menambah buruk kemampuan motorik pada tangan yang mengalami parese. Selama ini terapi yang sering dilakukan adalah bagaimana mengoptimalkan tangan yang mengalami parise agar mampu melakukan aktivitas sesuai kemampuannya. Latihan terus menerus dilakukan, namun keterbatasan ini akan menyebabkan pasien terus menerus melakukan kompensasi aktivitas dengan tangan yang sehat.

Latihan bilateral mengakibatkan peningkatan fasilitasi untuk kedua belahan hemisfer otak dan menunjukkan bahwa setelah latihan bilateral akan terjadi penurunan ICI dan peningkatan ICF (Intra Cortical Function) di kedua hemisfer. Hal ini dapat disimpulkan bahwa jika latihan hanya dilakukan pada tangan atau kaki yang parese saja maka dapat terjadi proses penghambatan pada hemisfer yang mengalami lesi, hal ini dapat menghambat dalam pemulihan ekstermitas yang mengalami parese. Selain itu ada satu hipotesis yang berkaitan dengan mekanisme inhibisi interhemisper antara hemisper dominan dan non dominan. Selama latihan unilateral akan terjadi inhibisi pada gerakan lengan kontra lateral. Pada inidividu normal mekanisme ini terjadi karena adanya aktivitas pada lengan dominan yang dapat menghambat kemampuan motorik pada sisi kontralateral.

Latihan ROM bilateral dapat menimbulkan rangsangan, sehingga meningkatkan aktivasi dari kimiawi, neuromuskuler dan muskuler. Otot polos pada ekstermitas mengandung filament aktin dan myosin yang mempunyai sifat kimiawi dan berinteraksi antara satu dan lainnya. Proses interaksi diaktifkan oleh ion kalsium dan adeno triphospat (ATP) yang selanjutnya dipecah menjadi adeno diposfat (ADP) untuk memberikan energi bagi kontraksi otot elstermitas. Rangsangan melalui neuromuskuler akan meningkatkan rangsangan pada serat saraf ekstermitas terutama saraf parasimpatis 
yang merangsang untuk produksi asetilcholin sehingga mengakibatkan kontraksi. Mekanisme melalui muskulus terutama otot polos ekstermitas yang akan meningkatkan metabolisme pada metokondria untuk menghasilkan ATP yang dimanfaatkan oleh otot polos ekstermitas sebagai energy untuk kontraksi dan meningkatkan tonus otot sehingga apabila dilakukan secara teratur dapat meningkatkan kekuatan otot.

\section{Efektifitas ROM Unilateral dan ROM Bilateral terhadap Kekuatan Otot}

Secara konsep latihan ROM dengan menggunakan pendekatan bilateral akan memberikan hasil yang lebih baik dibandingkan dengan pendekatan unilateral. Hal ini disebabkan karena latihan bilateral melibatkan dua hemisfer otak, sehingga mengaktivasi pada kedua sisi hemisfer otak. Pada latihan yang menggunakan pendekatan unilateral terjadi inhibisi pada gerakan lengan kontra lateral, sehingga latihan unilateral ini hanya mengaktivasi satu bagian otak. Hasil penelitian ini sejalan dengan hasil penelitian tentang bilateral arm training yang sudah dilakukan.

Pemberian latihan pasif ROM dapat meningkatkan kekuatan otot pada pasien stroke non hemoragik sebesar $83 \%$ pada nilai kekuatan otot 4 menurut hasil dari penelitian (Hutahaean et al., 2020). Begitu juga hasil penelitian Anggriani et al., (2018) yang menyatakan bahwa dengan pemberian latihan pasif ROM dapat meningkatkan kekuatan otot sebesar $52,2 \%$ dengan nilai 3 . Beberapa penelitian menyatakan terapi fisik dapat meningkatkan kekuatan otot salah satunya adalah latihan ROM. ROM termasuk lingkup rehabilitasi fisik, yang mana pasien stroke mengalami hemiparesis melakukan terapi ROM yang berfungsi untuk memperbaiki kekuatan dan koordinasi otot (Mulyadi et al., 2018).

Range Of Motion (ROM) jika dilakukan sedini mungkin dan dilakukan dengan benar dan secara terus-menerus akan memberikan dampak pada kekuatan otot. Latihan ROM ratarata dapat meningkatkan kekuatan otot serta pengaruh dari kekuatan otot. Pemberian metode range of motion aktif ini bertujuan untuk melatih kelenturan dan kekuatan otot serta sendi dengan cara menggunakan otot ototnya secara aktif atau mandiri sehingga menjadi lebih efektif dalam upaya meningkatkan kekuatan otot (Adriani \& Sary, 2019).

Dengan melakukan terapi ROM dua kali sehari, dalam lima hari pun terdapat peningkatan pergerakan sendi dari $64 \%$ menjadi $91 \%$. Pernyataan ini ditemukan dalam penelitian Chasanah tahun 2017 dengan instrumen lembar observasi ROM (Chasanah et al., 2017). Menurut penelitian studi kasus Basuki tahun 2018 dengan menggunakan instrumen lembar observasi ROM, menyatakan bahwa pelaksanaan terapi ROM pada pasien stroke dengan keluhan lemah otot dapat dilaksanakan pada hari keempat selama rawat inap (Basuki et al., 2018).

Penelitian ini sejalan dengan penelitian yang dilakukan oleh Rahmadani \& Rustandi (2019) yang membuktikan bahwa setelah diberikan latihan pasif ROM pada pasien stroke non hemoragik terjadi peningkatan kekuatan otot di Rumah Sakit Umum Curup ICU pada bulan Juni sampai Juli tahun 2019 dengan hasil sebelum dilakukan latihan nilai mean 1,60 dan setelah dilakukan latihan nilai mean 2,30.

Menurut Harahap (2019) hasil penelitiannya terdapat pengaruh latihan range of motion terhadap kekuatan otot pasien stroke non hemoragik dilakukan selama 3 kali sehari selama 7 hari di Puskesmas Pancur Batu Kabupaten Deli Serdang dengan hasil sebelum dilakukan latihan yaitu mayoritas pasien stroke tidak dapat melawan gravitasi sebanyak 1 pasien dan dapat melawan gravitasi sebanyak 5 pasien, jadi totalnya sebanyak 6 pasien. Sesudah diberikan latihan pasien dapat melawan gravitasi sebanyak 
2 pasien, melawan tahanan lemah sebanyak 3 pasien dan melawan tahanan kuat sebanyak 1 pasien, jadi totalnya sebanyak 6 pasien.

\section{SIMPULAN}

Latihan ROM pasif bilateral lebih efektif dalam meningkatkan kekuatan otot bila dibandingkan dengan latihan ROM pasif unilateral.

\section{SARAN}

Berdasarkan hasil penelitian ini, diharapkan dapat diaplikaskan dalam praktek keperawatan dengan melakukan aplikasi intervensi ROM unilateral maupun ROM bilateral, baik selama dalam masa perawatan maupun pada saat klien sudah diperbolehkan pulang/discharge planning, karena meskipun klien sudah diizinkan pulang masih memungkinkan klien pulang dalam kondisi parese/kelemahan, sehingga perlu dilakukan latihan untuk meningkatkan kemandirian klien sesuai dengan standar prosedur untuk meningkatkan fungsi motoriknya terutama kekuatan otot.

\section{DAFTAR PUSTAKA}

Adriani, A., \& Sary, N. (2019). Pengaruh Latihan Range of Motion (ROM) Aktif terhadap Peningkatan Kekuatan Otot Ekstremitas Bawah Lansia. Real in Nursing Journal, 2(3), 118. https://doi.org/10.32883/rnj.v2i3.564

Alifudin, M. R., \& Ediati, A. (2019). Pengalaman Menjadi Caregiver: Studi Fenomenologis Deskriptif pada Istri Penderita Stroke. Empati, 8(1), 111-116. https://ejournal3.undip.ac.id/index.php/empati/article/view/23583

Anggraini, G. D., Septiyanti, S., \& Dahrizal, D. (2018). Range Of Motion (ROM) Spherical Grip dapat Meningkatkan Kekuatan Otot Ekstremitas Atas Pasien Stroke. Jurnal Ilmu dan Teknologi Kesehatan, 6(1), 38-48. https://doi.org/10.32668/jitek.v6i1.85

Anggriani, A., Zulkarnain, Z., Sulaiman, S., \& Gunawan, R. (2018). Pengaruh ROM (Range Of Motion) terhadap Kekuatan Otot Ekstremitas pada Pasien Stroke Non Hemoragic. Jurnal Riset Hesti Medan Akper Kesdam I/BB Medan, 3(2), 64. https://doi.org/10.34008/jurhesti.v3i2.46

Anita, F., Pongantung, H., Ada, P. V., \& Hingkam, V. (2018). Pengaruh Latihan Range Of Motion terhadap Rentang Gerak Sendi Ekstremitas Atas Pasa Pasien Pasca Stroke di Makassar. JOIN (Journal of Islamic Nursing), 3(1), 97-105. http://journal.uin-alauddin.ac.id/index.php/join/article/view/5703

Basuki, L., Susilo, C. B., \& Jitowiyono, S. (2018). Penerapan ROM (Range Of Motion) pada Asuhan Keperawatan Pasien Stroke dengan Gangguan Mobilitas Fisik di RSUD Wates Kulon Progo. Politeknik Kesehatan Kemenkes Yogyakarta. http://eprints.poltekkesjogja.ac.id/id/eprint/1386

Chasanah, R. W. N., Ernawati, E., \& Marsito, M. (2017). Penerapan Terapi Range Of Motion (ROM) untuk Meningkatkan Pergerakan Sendi pada Pasien Stroke di Desa Wonosigro Kelurahan Gombong. Sekolah Tinggi Ilmu Kesehatan Muhammadiyah Gombong

Harahap, M. P. (2019). Pengaruh Range of Motion Pasif terhadap Peningkatan Kekuatan Otot Pasien Post Stroke di Wilayah Kerja Puskesmas Pancur Batu Kabupaten Deli Serdang Tahun 2019. Politeknik Kesehatan Medan. http://poltekkes.aplikasi-akademik.com/xmlui/handle/123456789/2151 
Hutahaean, R. E., Hasibuan, D., \& Taufik, M. (2020). Pengaruh Range of Motion terhadap Kekuatan Otot pada Pasien Stroke Iskemik di Rumah Sakit Umum HKBP Balige. Indonesian Trust Health Journal, 3(1), 278-282. https://doi.org/10.37104/ithj.v3i1.48

Indrawati, I., Sudjana, I. K., \& Sajidin, M. (2018). Pengaruh Kombinasi Terapi Latihan Range of Motion, Genggam Bola Karet dan Kompres Hangat terhadap Kekuatan Motorik Ekstremitas Atas dan Kadar Kortisol pada Klien Pasca Stroke Di RSU Dr. Wahidin Sudiro Husodo Mojokerto. Universitas Airlangga. http://repository.unair.ac.id/78459/2/TKP 93_18 Ind p.pdf

Johnson, W., Onuma, O., Owolabi, M., \& Sachdev, S. (2016). Stroke: A Global Response is Needed. In Bulletin of the World Health Organization, 94(9), 634A 635A. https://doi.org/10.2471/BLT.16.181636

Kristiani, R. B. (2018). Pengaruh Range of Motion Exercise terhadap Kekuatan Otot pada Pasien Stroke di Wilayah Puskesmas Sidotopo Surabaya. Jurnal Ners Lentera, $\quad 5(2)$,

149-155. http://journal.wima.ac.id/index.php/NERS/article/view/1796

Lestari, L. M. (2019). Pengaruh Pengelolaan Stress Keluarga terhadap Activity Daily Living (ADL) Pasien Post Stroke Iskemik. Jurnal Ilmu Keperawatan Medikal Bedah, 2(1), 37. https://doi.org/10.32584/jikmb.v2i1.236

Mulyadi, E., Wardy, A., \& Sofiani, Y. (2018). Perbandingan Pengaruh Range of Motion (ROM) Upper Extremity dengan Constraint Induced Movement Therapy (CIMT) terhadap Kekuatan Menggenggam Pada Pasien Post Stroke Di RSI Assyifa Kota Sukabumi. Lentera, 3(1), 93-106. https://jurnal.ummi.ac.id/index.php/lentera/article/view/217

Mutiarasari, D. (2019). Ischemic Stroke: Symptoms, Risk Factors, and Prevention. Medika Tadulako, Jurnal Ilmiah Kedokteran, 1(2), 36-44. http://jurnal.untad.ac.id/jurnal/index.php/MedikaTadulako/article/view/12337

Nababan, T., \& Giawa, E. (2019). Pengaruh ROM pada Pasien Stroke Iskemik terhadap Peningkatan Kekuatan Otot di RSU Royal Prima Medan tahun 2018. Jurnal Keperawatan Priority, 2(1), 1-8. http://jurnal.unprimdn.ac.id/index.php/jukep/

Nurazizah, I. S., Rahmi, U., \& Sulastri, A. (2020). Efektifitas Terapi Aktivitas Range Of Motion (ROM) pada Pasien Stroke Iskemik di Rumah Sakit: Literature Review. Universitas Pendidikan Indonesia. http://repository.upi.edu/id/eprint/50309

Nurtanti, S., \& Ningrum, W. (2018). Efektiffitas Range Of Motion (ROM) Aktif terhadap Peningkatan Kekuatan Otot pada Penderita Stroke. Jurnal Keperawatan GSH, 7(1), 14-18. https://journal.akpergshwng.ac.id/index.php/gsh/

Olviani, Y. (2017). Pengaruh Latihan Range Of Motion (ROM) Aktif-Asistif (Spherical Grip) terhadap Peningkatan Kekuatan Otot Ekstremitas Atas pada Pasien Stroke. Dinamika Kesehatan, 8(1), 250-257. https://ojs.dinamikakesehatan.unism.ac.id/

Rahmadani, E., \& Rustandi, H. (2019). Peningkatan Kekuatan Otot Pasien Stroke Non Hemoragik dengan Hemiparese melalui Latihan Range of Motion (ROM) Pasif. Journal of Telenursing (JOTING), 1(2), 354-363. https://doi.org/10.31539/joting.v1i2.985

Riskesdas. (2018). Hasil Utama Riset Kesehatan Dasar. Kementrian Kesehatan Republik Indonesia, 1-100. https://doi.org/https://doi.org/10.1088/1751$8113 / 44 / 8 / 085201$ 
Setyoadi, S., Nasution, T. H., \& Kardinasari, A. (2018). Family Support in Improving Independence of Stroke Patients. Jurnal Ilmu Keperawatan (Journal of Nursing Science), 6(1), 96-107. https://doi.org/10.21776/ub.jurnalilmukeperawatan

Syahrim, W. E. P., Azhar, M. U., \& Risnah, R. (2019). Efektifitas Latihan ROM terhadap Peningkatan Kekuatan Otot pada pasien Stroke: Study Systematic Review. MPPKI (Media Publikasi Promosi Kesehatan Indonesia): The Indonesian Journal of Health Promotion, 2(3), 186-191. https://doi.org/https://jurnal.unismuhpalu.ac.id/index.php/MPPKI/issue/view/58

Wahyuningsih, D. (2017). Pemberian Latihan ROM untuk Meningkatkan Kekuatan Otot pada Pasien Stroke di RSUD Dr. Soedirman Kebumen. Assiut Journal of

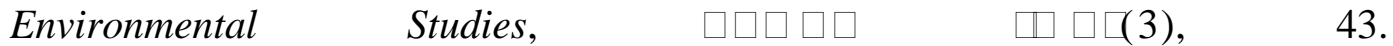
https://www.oreilly.com/library/view/designing-data-intensiveapplications/9781491903063/\%0Ahttp://shop.oreilly.com/product/063692003217 5.do\%0Ahttps://www.packtpub.com/web-development/getting-startedwebrtc\%0Ahttps://www.oreilly.com/library/view/getting-s 